\title{
Educating for resilience in the North: building a toolbox for teachers
}

\author{
$\underline{\text { Katie V. Spellman }}^{1}$
}

\begin{abstract}
Communities at far northern latitudes must respond rapidly to the many complex problems that are arising from changing climate. An emerging body of theoretical and empirical work has explored the role that education plays in enhancing the resilience and adaptability of social-ecological systems. To foster effective, local, and timely responses of high-latitude communities to climate-driven social-ecological change, educators need access to successful and efficient teaching tools to foster resilience-promoting feedbacks. The potential for existing teaching practices to address this need, however, must be investigated and communicated to teachers. Here, I review the education and sustainability science literature for attributes of resilience to which formal education can contribute, and I investigate teaching strategies that help to enhance these attributes. Using examples from Alaska, I examine the potential for systems thinking, metacognition, scenarios thinking, citizen science, and stewardship learning to promote resilience in social-ecological systems. I begin to develop a toolbox of teaching strategies for resilience education and suggest that policy for formal schools incorporates these tools into everyday teaching practice.
\end{abstract}

Key Words: Alaska; citizen science; human capital; metacognition; pedagogy; scenarios thinking; sense of place; social capital; socialecological resilience; systems thinking

\section{INTRODUCTION}

Learning is fundamental to resilience (Folke et al. 2009), or the capacity to respond and shape change in ways that sustain and develop the fundamental function, structure, identity, and feedbacks in a social-ecological system (Chapin et al. 2009). Only recently have education and social-ecological system resilience scholars begun to look at how the two fields might intersect and create learning opportunities that effectively target and contribute to resilience (Tidball and Krasny 2011). A growing body of literature explores the way that learning in informal education settings such as youth camps, community groups, and urban gardens can build attributes of resilient social-ecological systems such as social capital, improved ecosystem services, sense of place, and learning through experience (Fazey et al. 2007, Kofinas 2009, Krasny and Tidball 2009a, Tidball and Krasny 2010, Kudryavtsev et al. 2012a). Far less has been done to investigate the strategies or teaching tools available to compulsory school teachers to help foster these resilience-building outcomes (but see Sriskandarajah et al. 2010). In a recent special feature of Ecology and Society, formal schooling attainment was linked in numerous studies to decreases in disaster vulnerability and enhanced resilience (reviewed in Muttarak and Lutz 2014). Formal school teachers around the globe compose a large potential force to shape the ability of society to navigate the rapid changes that currently challenge us. Sterling (2010) notes that resilience scholars have called for radical transformations in the way society thinks and learns toward a more holistic, systematic, integrative, and participatory mode, but he argues that this transformation is unlikely to occur unaided. There is a clear need at the intersection of resilience and education research to identify, test, and refine teaching strategies that can best encourage and aide formal school teachers in building the capacities in their students necessary for managing rapid global changes.

There is perhaps no place where this need is more urgent than in high-latitude northern systems, which are in the midst of unprecedented rates of social and ecological change (Hinzman et al. 2005, Huntington et al. 2007). Increasing fire frequency, permafrost degradation, coastal erosion, spread of invasive species, decreasing sea ice extent, increasing human population, and accumulating human impacts on ecosystems, among other changes, interact to create challenges that arctic and subarctic communities must address to sustain themselves (ACIA 2004). In Alaska, public health, transportation, industry, and public works are all being affected by the changing conditions (Markon et al. 2012). Environmental changes have also threatened many indigenous Alaskan villages, forcing migration of communities due to accelerated erosion, flooding, or permafrost thaw (Maldonado et al. 2013). Changes in disturbance regimes and access have also disrupted traditional subsistence food practices (Kofinas et al. 2010). A rapidly changing climate has hastened many of these changes (ACIA 2004) and decreased the response time that northern communities have to tackle the complex problems that arise. Alaskan teachers are a large systematic force and asset for helping to create a society able to navigate rapid climate-driven change and have a heightened need to obtain teaching tools that most effectively and efficiently foster socialecological resilience.

My objective here is to identify and discuss teaching strategies for $\mathrm{K}-16$ classroom teachers in Alaska, and beyond, that target specific attributes of social-ecological system resilience. I first review some of the attributes of resilient social-ecological systems that classroom teaching strategies could support. I then examine some of the learning tools that have both been proposed within the resilience literature to enhance the resilience of a socialecological system and been developed and tested within the education literature. I provide examples of implementing these learning tools in formal education settings, and where possible, in Alaska. I conclude with a discussion of potential hurdles and solutions for incorporating these tools into common teaching practices.

\section{RESILIENCE ATTRIBUTES AND EDUCATION}

The sustainability of a system is often thought of as the longterm maintenance of or investment in the capital within a system (Chapin et al. 2009). Forms of capital include natural, built, human, and social capital (Arrow et al. 2004). The concept of 
capital has provided a way to quantify or assess whether a management decision or social practice is sustainable (Arrow et al. 2004). Multiple scholars within the resilience literature have suggested that communities with higher levels of human and social capital not only can sustain themselves, but are better able to respond to and shape changes in the social-ecological system (i.e., more resilient; Ostrom 2000, Adger 2003, Walker and Salt 2006, Plummer and FitzGibbon 2007, Muttarak and Lutz 2014). In their conceptual framework on resilience and education, Tidball and Krasny $(2010,2011)$ identify social capital, particular aspects of human capital, and sense of place as key outcomes of education that generate resilience-supporting feedbacks within a social-ecological system. Human capital, social capital, and sense of place are constructs that span multiple disciplines, scales, and definitions (Kudryavtsev et al. 2012a,b, Krasny et al. 2013). In this section, I draw upon education and resilience research to discuss and define these elements within Tidball and Krasny's $(2010,2011)$ framework.

\section{Human capital}

In his research on youth education, Coleman (1988) defines human capital as the skills and capabilities that enable a person to act in new ways. Within the resilience literature, Arrow et al. (2004) define human capital as the capacity of people to accomplish their goals. Both agree that human capital is increased by learning (Coleman 1988, Arrow et al. 2004). In fact, most social science studies on the subject use the level of education attained, or level of education attained by parents in the case of youth, as the primary indicator of human capital (reviewed in Ferguson 2006).

Both current trends in education policy and practice, and thinking within resilience theory call for a shift in investment in human capital from the more traditional investment in knowledge aquisition to investment in critical and reflective thinking skills (Duschl et al. 2007, Fazey et al. 2007, Sterling 2010, NRC 2012). In their U.S. National Research Council education research review of best practices in science education, Duschl et al. (2007) advocated that the developers of mandated curricula and science education standards shift focus from science as a collection of facts to science as a reflective and iterative process. The U.S. national Framework for K-12 Science Education (NRC 2012) responds to this recommendation by emphasizing the crosscutting concepts and practices of science such as systems modelling, stability, and change, throughout the newest national science standards (Next Generation Science Standards). Human capital investments that have been advocated in the resilience literature primarily include thinking skills that improve people's ability to anticipate, understand, reflect upon, and learn from change within a complex social-ecological system (Carpenter 2002, MEA 2005, Fazey et al. 2007, Ascher 2009, Chapin et al. 2009, Kofinas 2009, Tschakert and Dietrich 2010, Tidball and Krasny 2011). Understanding which teaching tools can best help teachers achieve this shift in human capital investment will clearly aid this effort. It can be argued that the goal of all education strategies is to increase human capital. Therefore, I identify only those teaching strategies that increase the abovementioned specific aspects of human capital advocated in the resilience literature and recent education reforms.

\section{Social capital}

Coleman (1988) defines social capital as relationships between people that facilitate action. In a formal education setting, this includes relationships between students, parents, educators, and the broader community that promote learning (Coleman 1988). The concept of social capital has been used widely to help explain academic success in at-risk youth (Coleman 1988, Furstenberg and Hughes 1995, Dyk and Wilson 1999) and youth development outcomes (reviewed in Ferguson 2006). Coleman (1988) argues that investment in social capital within school systems is as important as the more traditional investment in human capital in determining the ability of students and communities to learn successfully and act in new ways. Within the resilience literature, Ahn and Ostrom (2008) go beyond the Coleman (1988) definition of social capital to include the values and relationships that have been created in the past that can be used to navigate socialecological problems in the present or future.

In a systematic review of education studies using social capital as a guiding construct, Ferguson (2006) identifies community social capital as a major contributor to a child's well-being. Education researchers, social scientists, and resilience scholars typically group indicators of community social capital into three categories: social support networks, civic engagement in local institutions, and trust and safety (Putnam 1995, Ferguson 2006, Ahn and Ostrom 2008). In their pioneering literature synthesis and pilot study, Krasny et al. (2013) developed a conceptual model that links social capital to attributes of social-ecological resilience that environmental education can stimulate, including positive youth development, community well-being, natural capital, and ecosystem services. Their pilot survey measuring social capital in inner-city youth found that students involved in communitybased environmental stewardship projects showed increased informal socialization and diversity of friendships, two indicators of social support networks in youth, compared to students who did not participate in similar environmental education programs (Krasny et al. 2013). They propose that by continuing to engage students in these types of environmental stewardship projects, amplifying feedbacks for resilience can be created for a community at the interface of education and local resource management (Krasny et al. 2013).

\section{Sense of place}

As defined by Stedman (2002:561), sense of place is the "meanings and attachment to a setting held by an individual or group." This definition highlights the two major components of the sense of place construct: (1) place meaning, or the symbolic meanings that people assign to places; and (2) place attachment, or the bond between people and their environment (Stedman 2002). Sense of place has received increasing attention in the resilience literature as an attribute within individuals or groups of people that can foster social-ecological resilience (Kudryavtsev et al. 2012a,b). Sense of place has also received prominent attention in child development and education literature as being critical to youth well-being (Chawla 1992, Wilson 1997, Capra 1999, Louv 2008, Russell et al. 2013). Several empirical studies have demonstrated that the meanings and attachments people give to places can stimulate human capital by increasing pro-environmental behaviors, concerns, and intentions (Stedman 2002, Walker and 
Chapman 2003, Ryan 2005, Rioux 2011). Other empirical and theoretical studies suggest that the learning and knowledge about a place (existing human capital) can change the attachment and meaning a person gives to the place (Tuan 1977, Semken et al. 2009). When strong sense of place is held by a group, several authors theorize that social capital can be increased by connecting people through a common concern and identity, increasing the capacity for collective action to manage natural resources (Ostrom 1990, Miller 1992, Ahn and Ostrom 2008). Eisenhauer et al. (2000) found that social interactions can also be an important contributor to developing place attachment. These studies suggest that sense of place has a reciprocal relationship with human and social capital, with these stocks for resilience contributing to sense of place and vice versa. This amplifying feedback may promote resilience by increasing the capacity for and likelihood of individuals or communities actively managing changes in social-ecological systems.

\section{REVIEW OF RESILIENCE LEARNING TOOLS}

Specific teaching practices have been suggested in the resilience literature to help enhance human capital, social capital, or sense of place. These strategies include systems thinking (Sterling 2003, Kofinas 2009), metacognition (Fazey et al. 2007), scenarios thinking (MEA 2005, Kofinas 2009), citizen science (Berkes 2002, Jordan et al. 2012, Tidball and Krasny 2012), and stewardship learning (Kevany 2007, Krasny and Tidball 2009a,b). I discuss these five tools in the following section because all have been thoroughly researched within the education literature and have the potential to be applied practically in formal classroom settings to target learning toward the attributes of resilient socialecological systems.

\section{Systems thinking}

Systems thinking is a mode of teaching that shifts the focus of learning beyond isolated facts and concepts to emphasize their relationships with other concepts in a systems context (Jordan et al. 2009, Boersma et al. 2011). Students are challenged to consider some of the fundamental properties of complex systems such as nonlinear relationships (i.e., amplifying and stabilizing feedbacks) between system parts, system parts operating at multiple spatial or temporal scales, or emergent properties of systems that only occur when the multiple parts interact (Meadows 2008, Ben-Zvi Assaraf and Orion 2010). Jordan et al. (2009) propose that systems thinking can aid a student's construction of their own knowledge (as in Driver et al. 1994). This is achieved by giving students practice developing mental models of abstract social-ecological concepts and fitting their new learning about a system within the constructs of their prior knowledge (Crawford and Jordan 2013).

Learners must be taught how to think in systems; systems thinking is not necessarily an innate skill (Sterman and Sweeny 2007). Students as young as 8 years old can gain systems thinking skills and apply them within a social-ecological context (Wylie et al. 1998), and these sorts of learning interventions can have lasting effects (Ben-Zvi Assaraf and Orion 2010). Placing learning within a social-ecological systems context may further enhance the effect this tool has on fostering resilience (Sterling 2003, Kyburz-Graber et al. 2006, Krasny 2009). This learning strategy has been employed in resource management planning workshops to help visualize the effects of climate change on communities (Cone et al. 2012, 2013, Gray et al. 2012). Cone et al. (2012), for example, found that by using concept mapping to facilitate systems thinking, participants were better able to gauge the complex risks climate change might bring to their community and better able to plan to reduce those risks. Within youth education settings, Crawford and Jordan (2013) advocate for greater use of systems thinking and practice with conceptual modeling in science and environmental education to build student capacity to think critically about our changing social-ecological systems.

In Alaska, systems thinking has taken a prominent role as a learning strategy in the Alaska Seas and Rivers Curriculum (Alaska Sea Grant 2009). The enduring understandings that the curriculum uses to frame the learning goals of the lessons include the following: "watersheds, rivers, wetlands, and the one big ocean of the world are an interconnected system;" "the ocean and humans are inextricably linked;" and "connections between humans and the ocean are important." Several lessons include drawing or building models of local or global scale socialecological systems. Table 1 lists practical methods that have been used in classrooms in places other than Alaska to apply systems thinking in formal education programs.

\section{Metacognition}

Both education and resilience scholars have argued that an increased emphasis on metacognition, or the knowledge of and ability to regulate one's own thinking and learning, is essential to building adaptive capacity of individuals and societies (Bransford et al. 2000, Fazey et al. 2007). Metacognition is inherent in the concept of multiple loop learning, which combines metacognition with group learning from actions and is commonly cited in adaptive management and resilience literature (Argyris and Schön 1978, Senge 1990, Kofinas 2009). A broad and diverse body of education literature has explored the effect of metacognition on learning (reviewed in Dignath and Büttner 2008) as well as the many implementation strategies that have been developed for classroom use (see Table 1 for examples). Metacognitive ability can increase with age (Flavell et al. 1995) and with practice throughout our lives (Brown and DeLoache 1978, Doran and Cameron 1995). Compared to students who learned through other approaches, students who practiced metacognitive learning improved their level of discourse on ecological topics and showed longer term retention of their ecology understanding (Blank 2000). Further, students who practice metacognition showed greater fluid intelligence, the kind of knowledge that allows for problem solving when faced with new information or stimuli (Rosencwajg 2003). These empirical studies suggest that metacognitive teaching approaches may be useful in enhancing student ability to apply knowledge flexibly and restructure knowledge in the face of rapid environmental change.

In a recent study in Alaska, Spellman (2015) conducted an experiment to test whether explicit metacognitive practice could improve environmental problem solving skills on a local rapid social-ecological change issue: non-native plant invasion in the boreal forest. One-half of 108 seventh grade students had daily metacognitive practice embedded into their lessons in the form of metacognitive journaling exercises while the other half of the students did not (Spellman 2015). Compared to students who did not complete daily metacognitive journaling, students who practiced metacognition tended to show greater improvement in 
Table 1. Descriptions of some practical implementation strategies for resilience learning tools in $\mathrm{K}-16$ classrooms.

\begin{tabular}{|c|c|c|}
\hline Learning tool & Implementation strategy & How it works \\
\hline \multirow[t]{3}{*}{ Systems thinking } & Systems drawings & $\begin{array}{l}\text { Students draw illustrations of the different system components showing relationships and } \\
\text { processes within the system (Ben-Zvi Assaraf and Orion 2005). }\end{array}$ \\
\hline & Concept maps & $\begin{array}{l}\text { Students are given a set of words representing system components and processes. Students } \\
\text { arrange the words in a diagram and illustrate connections between the words to show their } \\
\text { relationships (Ben-Zvi Assaraf and Orion 2005). }\end{array}$ \\
\hline & Computer-based modeling & $\begin{array}{l}\text { Students conceptualize a system in a user-friendly modeling interface and convert the } \\
\text { relationships (including nonlinear relationships and feedbacks) into numerical formulas } \\
\text { (Hung 2008, Riess and Mischo 2010). }\end{array}$ \\
\hline \multirow[t]{3}{*}{ Metacognition } & Metacognitive journaling & $\begin{array}{l}\text { Students reflect on their learning by checking the development or status of their ideas. } \\
\text { Students make sense of their idea, place it in the constructs of their prior knowledge, and } \\
\text { reflect on the fruitfulness of the idea (i.e., does the idea help solve problems or encourage } \\
\text { other ideas; Hennessey 1991, Blank 2000). }\end{array}$ \\
\hline & Metacognitive illustration & $\begin{array}{l}\text { Students draw illustrations of themselves and what they are thinking in relation to different } \\
\text { learning tasks (Wall et al., unpublished manuscript: } \underline{\text { http://www.ncl.ac.uk/cflat/news/ }} \\
\text { documents/WallPupilviewstemplatespaper.pdf). }\end{array}$ \\
\hline & Constructivist metaphor & $\begin{array}{l}\text { Classroom dialog periodically references the phrase "learning is constructing" during } \\
\text { learning activities (Thomas and McRobbie 2001). }\end{array}$ \\
\hline \multirow[t]{3}{*}{ Scenarios thinking } & $\begin{array}{l}\text { Backward and forward } \\
\text { timeline creation }\end{array}$ & $\begin{array}{l}\text { Students place a desired future at the end of a timeline and construct the events that could } \\
\text { lead from the desired state back to the present, or vice versa, starting at the present and } \\
\text { creating a timeline of decisions that lead to variety of unknown futures (Jones et al. 2011). }\end{array}$ \\
\hline & Futures wheels & $\begin{array}{l}\text { Students use concentric wheels to visualize the effects of events, with a future event placed } \\
\text { in the middle, direct effects of that event in a ring around the future event, and indirect } \\
\text { effects in succeeding rings (Jones et al. 2011). }\end{array}$ \\
\hline & Cross impact matrices & $\begin{array}{l}\text { Students assess positive or negative interactions between possible future events by writing } \\
\text { events horizontally and vertically along a grid (Jones et al. 2011). }\end{array}$ \\
\hline
\end{tabular}

their critical thinking skills on an environmental problem-solving assessment (Spellman 2015). This experiment demonstrates that explicit instruction in metacognition can increase the kinds of human capital thought to build resilience by creating better critical thinkers and social-ecological problem solvers.

\section{Scenarios thinking}

In general, both adults and youth have a poor ability to think about the future (Ornauer et al. 1976, Hicks and Holden 1995, Ascher 2009), but it is a skill that can be taught (Liedtka 1998). Scenarios thinking is a tool that encourages learners to create multiple stories about possible futures based on a range of decisions in complex settings (Mietzner and Reger 2005). By imagining multiple possible paths for the future, individuals, communities, or societies can better understand their options, identify priorities for action, and plan for a positive future (Mietzner and Reger 2005, Carpenter et al. 2006). The learning tool is used in natural resource management, including in Alaska, to help communities faced with resource dilemmas choose paths that will best help them achieve desired management outcomes in the future (Chapin et al. 2003, Peterson et al. 2003, Carpenter et al. 2006, Ernst and van Riemsdijk 2013).

The explicit practice of scenarios thinking in educational settings could also enhance a person's willingness to engage in stewardship activities. Hicks and Holden (1995) found that when people imagine the future, more often than not, they imagine local and global problems staying the same or getting worse than they are now. These pessimistic visions of the future can lead people to believe that their present actions will not make a difference in the future and provides them with little motivation for behavior changes (Hicks and Holden 1995). By incorporating scenarios thinking into learning experiences (examples in Table 1), educators could improve the forms of human capital that contribute to resilience by increasing people's skills at imagining a desirable future and believing their actions can make a contribution toward achieving it (as in Hicks and Holden 1995, Mietzner and Reger 2005). Further, by practicing scenarios thinking, learners become better prepared to deal with uncertainty and surprises (Mietzner and Reger 2005).

\section{Citizen science}

Citizen science refers to partnerships between scientists and nonscientists to conduct authentic scientific research on a topic of interest or concern (Conrad and Hiltchey 2011, Jordan et al. 2012). It includes a spectrum of learning experiences from citizen as data collector for scientists, with predefined questions or longterm monitoring goals, to citizen as scientist, collecting and analyzing data on community-generated questions with the assistance of experts (Conrad and Hiltchey 2011, Shirk et al. 2012). Citizen science can also take the form of communityscientist partnerships to document change through the collection of local and traditional ecological knowledge (Bäckstrand 2003). The usefulness of citizen science as both an ecological methodology and a learning tool has received increasing attention in the peer-reviewed literature over the past two decades (Silvertown 2009, Bonney et al. 2014).

Many of the documented outcomes of citizen science programs show potential for gradual shifts in the way scientists and community members think, their skills for solving socialecological problems, and what they value (Turnbull et al. 2000, Brossard et al 2005, Jordan et al. 2011, Dickinson et al. 2012, Jordan et al. 2012). Through collaborative action and dialog, 
citizen science has also been suggested as a tool to build elements of social capital such as social networks and trust between scientists, land managers, and a diverse public (Bäckstrand 2003, Jordan et al. 2012, Pandya 2012). Berkes (2002) suggests that citizen science can be used as an important strategy to create crossscale linkages in resource management. Citizen science gives local stakeholders the opportunity to contribute to the scientific knowledge that informs the resource management policies being created at regional or national scales (Berkes 2002). Building on this idea, Tidball and Krasny (2012) used examples of citizen science in post-disaster cases to demonstrate how the learning tool can be used in adaptive co-management. As suggested by Berkes (2002), Tidball and Krasny (2012) argue that citizen science can help tighten the feedback loops between stakeholders and management actions and build resilience in a socialecological system.

Citizen science has also been associated with a deepened sense of place (Evans et al. 2005). Evans et al. (2005) analyzed outcomes from a backyard bird ecology citizen science program using interviews and surveys and found increases in participants' sense of place. They define sense of place as the knowledge and awareness of and willingness to care for a certain place (Evans et al. 2005). This definition falls more within the place attachment side of the sense of place construct defined by Stedman (2002) than within the place meaning aspect of the construct. Feeling more connected and aware of the events in their backyards after spending time collecting data, long-time residents started noticing and identifying different bird calls. In addition, more than half the participants had changed a stewardship behavior in relationship to their yard (Evans et al. 2005).

One citizen science program in Alaska, the Melibee Project, teams volunteers from across Alaska with ecologists at the University of Alaska to address the potential for competition between native berry plants (Vaccinium spp.) and an invasive plant (Melilotus albus) for pollinators (Spellman 2015). Trained volunteers track the flowering phenology of the focal species throughout the growing season. Compared to before they participated in the project, Melibee Project volunteers increased their scientific knowledge and process skills through volunteer training and teacher workshops. They reported increases in their awareness of invasive plants, awareness of the phenological events around them, and frequency of engaging in stewardship activities such as pulling invasive plants, participating in community weed removal events, or reporting suspicious plants to experts (Spellman 2015). In addition to these human capital increases, the Melibee Project facilitated collaboration and networking among K-16 students, teachers, other volunteers, scientists, land managers, and tribal leaders for science-based resource management (Bestelmeyer et al. 2015).

\section{Stewardship learning}

Stewardship learning is a strategy whereby learners make an active contribution to improving their environment while learning about the processes and issues that they are working toward bettering (Cramer 2008). It necessitates drawing students into community life and engaging them in an ecological setting (Kevany 2007). Stewardship learning can often lead to improvements in ecosystem structure and functioning, and builds skills and values such as planning ability, scientific knowledge, sense of place, and understanding of social-ecological systems (Krasny and Tidball 2009b, Tidball and Krasny 2010). For example, the stewardship learning in the Cornell Civic Ecology Lab's urban gardening program provided participants with skills essential to the adaptive co-management process such as learning as a group through experience, experimentation, and innovation (Krasny and Tidball $2009 b$ ). In another study comparing students who participated in environmental and nonenvironmental youth programs in New York City, Kudryavtsev et al. (2012a) found that students engaged in environmental stewardship developed stronger place attachments and place meanings than the students in nonenvironmental programs. They propose that educational programs that engage students in meaningful stewardship activities within their own communities can be a source of important resilience building feedbacks that immediately improve ecosystems and build the sense of place necessary to sustain them (Kudryavtsev et al. 2012a). Similar social and ecological benefits have been documented in myriad other studies on the effects of stewardship learning (reviewed in Billig 2000).

The Center for Alaskan Coastal Studies, an environmental education nonprofit in Homer, Alaska, has been running a stewardship learning program called Kachemak CoastWalk since 1984 (CACS 2014). Every September, approximately 600 volunteers, including several hundred $\mathrm{K}-16$ students and teachers, remove marine debris and conduct biodiversity and human impact surveys of adopted beach zones (CACS 2014). The program gives students an opportunity to learn about marine debris and coastal change through an in-classroom curriculum (Trowbridge et al. 2004) and immerses them in large-scale community action on these issues. Changes in participant sense of place, particularly place attachment, have been documented anecdotally as a result of the stewardship project (Sigman and Trowbridge 2004), and the community art program that has become a part of the annual effort has allowed local artists to visually express the place meanings that they have developed using the marine debris they remove from the beach (CACS 2014).

\section{Institutional hurdles and policy suggestions}

The manner in which human and social capital assets are built and used depends largely on the institutions that guide these forms of capital (Arrow et al. 2004). I next discuss curriculum policy, evaluation, and teacher training as aspects of educational institutions that present both potential hurdles and avenues for facilitating the incorporation of the learning tools discussed above into regular classroom teaching practice.

\section{Resilience learning tools in compulsory curriculum}

Mandated curriculum at local, state, and national scales provides a structure for new trends and best practices in education to be broadly disseminated and applied. Within compulsory public education systems, mandated curriculum could help the resilience-building learning tools discussed here to reach a high proportion of the school-aged population. Curriculum policies that promote concepts of sustainability and resilience have been mandated in some national education agendas, for example, futures thinking in New Zealand and Australia (Jones et al. 2011) and sustainability concepts in France (Simonneaux and Simonneaux 2012). The resilience framework for education 
proposed by Tidball and Krasny $(2010,2011)$ may serve as an important tool for curriculum developers and teachers seeking to align curriculum learning goals with resilience-based outcomes.

Evaluation of learning within a resilience framework In their study of the integration of environmental education into local curriculums in Taiwan, Yueh et al. (2010) found that more holistic and action-oriented student learning outcomes were more difficult to measure than in traditional school subjects because they are hard to capture with the available assessment tools such as written tests. If the shift toward greater state-mandated emphasis on process skills in curriculum continues (e.g., NRC 2012), learning tools that support resilience may be increasingly practical for educators to use and evaluate. Learning progressions, i.e., models for student learning that take concepts or skills through increasing levels of complexity and sophistication (Duschl et al. 2011), could potentially be used to structure, guide, and measure student progress in resilience thinking skills and to construct curricula with resilience-based learning outcomes (BenZvi Assaraf and Orion 2005, Lee and Liu 2010, Robertson et al. 2012).

Teacher training to support resilience learning

A major institutional hurdle that must be overcome to ensure learning for resilience within schools is a lack of teacher training in the pedagogies discussed here. For example, many teachers lack the skills and knowledge to teach systems thinking or integrated social-ecological systems (Sterman and Sweeny 2007, Almeida and Vasconcelos 2011). In Alaska, one of the first steps toward creating a society that has the capability to respond and adapt to rapid change should be to provide professional development workshops and core coursework for current and prospective teachers on the thinking skills and learning tools discussed here.

\section{CONCLUSIONS}

Education and resilience theorists have called for further investigation of the role education can play in sustaining socialecological systems in the face of changing climate (Fazey et al. 2007, Krasny et al. 2009, Krasny and Tidball 2009a, Tidball and Krasny 2010, 2011). In response to this call, I investigated attributes of resilient social-ecological systems to which formal education can contribute, and I present the beginning of a resilience teaching toolbox for $\mathrm{K}-16$ educators. The resilience learning tools suggested here are clearly insufficient in and of themselves to meet the needs of the scale and rate of climate change in Alaska or elsewhere. However, this is an initial step toward thinking about practical applications for resilience theory in classrooms. Future research on pedagogies that can best build resilience is needed, particularly within the arctic and subarctic communities undergoing the most rapid change. Formal school teachers can play an enormous role in facilitating the transformations in the way society thinks and learns that are required for resilience (e.g., Sterling 2010). The intersection between education and resilience research is ripe for the picking to aid teachers in this profound task.

Responses to this article can be read online at: http://www.ecologyandsociety.org/issues/responses. $\mathrm{php} / 7243$

\section{Acknowledgments:}

I greatly appreciate the thoughtful reviews of this manuscript by $F$. S. Chapin III, G. Kofinas, A. Lovecraft, C. P. H. Mulder, and two anonymous reviewers. The research for this paper was supported by National Science Foundation IGERT grant (Grant \#0654441) and by USDA grant ALKR-2009-04931 (PIs: C. P. H. Mulder and M. L. Carlson).

\section{LITERATURE CITED}

ACIA. 2004. Impacts of a warming climate: Arctic climate impact assessment. Cambridge University Press, Cambridge, UK.

Adger, W. N. 2003. Social capital, collective action, and adaptation to climate change. Economic Geography 79 (4):387-404. http://dx.doi.org/10.1111/j.1944-8287.2003.tb00220. $\underline{x}$

Ahn, T. K., and E. Ostrom. 2008. Social capital and collective action. Pages 70-100 in D. Castiglione, J. W. van Deth, and G. Wolleb, editors. The handbook of social capital. Oxford University Press, Oxford, UK.

Alaska Sea Grant. 2009. Alaska seas and rivers curriculum. Alaska Sea Grant, Anchorage, Alaska, USA. [online] URL: http:// seagrant.uaf.edu/marine-ed/curriculum/.

Almeida, A., and C. Vasconcelos. 2011. Teachers' perspectives on the human-nature relationship: implications for environmental education. Research in Science Education 43(1):299-316. http:// dx.doi.org/10.1007/s11165-011-9272-z

Argyris, C., and D. A. Schön. 1978. Organizational learning: a theory of action perspective. Addison-Wesley, Reading, Massachusetts, USA.

Arrow, K., P. Dasgupta, L. Goulder, G. Daily, P. Ehrlich, G. Heal, S. Levin, K.-G. Mäler, S. Schneider, D. Starrett, and B. Walker. 2004. Are we consuming too much? Journal of Economic Perspectives 18(3):147-172. http://dx.doi.org/10.1257/0895330042162377

Ascher, W. 2009. Bringing in the future: strategies for farsightedness and sustainability in developing countries. University of Chicago Press, Chicago, Illinois, USA. http://dx.doi.org/10.7208/ chicago/9780226029184.001.0001

Bäckstrand, K. 2003. Civic science for sustainability: reframing the role of experts, policy-makers and citizens in environmental governance. Global Environmental Politics 3(4):24-41. http://dx. doi.org/10.1162/152638003322757916

Ben-Zvi Assaraf, O., and N. Orion. 2005. Development of system thinking skills in the context of earth systems education. Journal of Research in Science Teaching 42(5):518-560. http://dx.doi. org/10.1002/tea.20061

Ben-Zvi Assaraf, O., and N. Orion. 2010. Four case studies, six years later: developing system thinking skills in junior high school and sustaining them over time. Journal of Research in Science Teaching 47(10):1253-1280. http://dx.doi.org/10.1002/tea.20383

Berkes, F. 2002. Cross-scale institutional linkages: perspectives from the bottom up. Pages 293-321 in E. Ostrom, T. Diez, N. 
Dolsak, P. C. Stern, S. Stovich, and E. U. Weber, editors. The drama of the commmmons. National Academy Press, Washington, D.C., USA.

Bestelmeyer, S. V., M. M. Elser, K. V. Spellman, E. B. Sparrow, S. Haan-Amato, and A. Keener. 2015. Collaboration, interdisciplinary thinking, and communication: new approaches to K-12 education. Frontiers in Ecology and the Environment 13 (1):37-43. http://dx.doi.org/10.1890/140130

Billig, S. H. 2000. Research on K-12 school-based servicelearning: the evidence builds. Phi Delta Kappan 81:658-664.

Blank, L. M. 2000. A metacognitive learning cycle: a better warranty for student understanding? Science Education 84 (4):486-506. http://dx.doi.org/10.1002/1098-237X(200007)84:4<486:: AID-SCE4>3.0.CO;2-U

Boersma, K., A. J. Waarlo, and K. Klaassen. 2011. The feasibility of systems thinking in biology education. Journal of Biological Education 45(4):190-197. http://dx.doi.org/10.1080/00219266.2011.627139

Bonney, R., J. L. Shirk, T. B. Phillips, A. Wiggins, H. L. Ballard, A. J. Miller-Rushing, and J. K. Parrish. 2014. Next steps for citizen science. Science 343:1436-1437. http://dx.doi.org/10.1126/ science. 1251554

Bransford, J. D., A. L. Brown, and R. R. Cocking. 2000. How people learn: brain, mind, experience, and school. National Academy Press, Washington, D.C., USA.

Brossard, D., B. Lewenstein, and R. Bonney. 2005. Scientific knowledge and attitude change: the impact of a citizen science project. International Journal of Science Education 27 (9):1099-1121. http://dx.doi.org/10.1080/09500690500069483

Brown, A. L., and J. S. DeLoache. 1978. Skills, plans, and selfregulation. Pages 3-36 in R. S. Siegler, editor. Children's thinking: what develops? Lawrence Erlbaum, Hillsdale, New Jersey, USA.

CACS [Center for Alaskan Coastal Studies]. 2014. Kachemak Bay coastwalk. Center for Alaskan Coastal Studies, Homer, Alaska, USA. [online] URL: http://www.akcoastalstudies.org/outreach/ international-coastal-cleanup/kachemak-bay-coastwalk.html.

Capra, F. 1999. Ecoliteracy: the challenge for education in the next century. Center for Ecoliteracy, Berkeley, California, USA. [online] URL: http://cccensw.org.au/rattlerresources/ecoliteracy. pdf.

Carpenter, S. R. 2002. Ecological futures: building an ecology of the long now. Ecology 83(8):2069-2083. http://dx.doi. org/10.1890/0012-9658(2002)083[2069:EFBAEO]2.0.CO;2

Carpenter, S. R., E. M. Bennett, and G. D. Peterson. 2006. Scenarios for ecosystem services: an overview. Ecology and Society 11(1): 29. [online] URL: http://www.ecologyandsociety. org/vol11/iss1/art29/.

Chapin, F. S. III, G. P. Kofinas, and C. Folke, editors. 2009. Principles of ecosystem stewardship: resilience-based natural resource management in a changing world. Springer, New York, New York, USA. http://dx.doi.org/10.1007/978-0-387-73033-2

Chapin, F. S. III, T. S. Rupp, A. M. Starfield, L. DeWilde, E. S. Zavaleta, N. Fresco, J. Henkelman, and A. D. McGuire. 2003. Planning for resilience: modeling change in human-fire interactions in the Alaskan boreal forest. Frontiers in Ecology and the Environment 1(5):255-261. http://dx.doi.org/10.1890/1540-9295 (2003)001[0255:PFRMCI]2.0.CO;2

Chawla, L. 1992. Childhood place attachments. Pages 63-86 in I. Altman and S. M. Low, editors. Place attachment. Springer, New York, New York, USA. http://dx.doi.org/10.1007/978-1-4684-8753-4 4

Coleman, J. S. 1988. Social capital in the creation of human capital. American Journal of Sociology 94:S95-S120. http://dx. doi.org/10.1086/228943

Cone, J., S. Rowe, J. Borberg, and B. Goodwin. 2012. Community planning for climate change: visible thinking tools facilitate shared understanding. Journal of Community Engagement and Scholarship 5(2):7-18.

Cone, J., S. Rowe, J. Borberg, E. Stancioff, B. Doore, and K. Grant. 2013. Reframing engagement methods for climate change adaptation. Coastal Management 41(4):345-360. http://dx.doi. org/10.1080/08920753.2013.803926

Conrad, C. C., and K. G. Hilchey. 2011. A review of citizen science and community-based environmental monitoring: issues and opportunities. Environmental Monitoring and Assessment 176 (1-4):273-291. http://dx.doi.org/10.1007/s10661-010-1582-5

Cramer, J. R. 2008. Reviving the connection between children and nature through service-learning restoration partnerships. Native Plants 9(3):278-286.

Crawford, B. A., and R. Jordan. 2013. Inquiry, models, and complex reasoning to transform learning in environmental education. Pages 105-123 in M. E. Krasny and J. Dillon, editors. Trading zones in environmental education: creating transdisciplinary dialogue. Peter Lang, New York, New York, USA.

Dickinson, J. L., J. Shirk, D. Bonter, R. Bonney, R. L. Crain, J. Martin, T. Phillips, and K. Purcell. 2012. The current state of citizen science as a tool for ecological research and public engagement. Frontiers in Ecology and the Environment 10:291-297. http://dx.doi.org/10.1890/110236

Dignath, C., and G. Büttner. 2008. Components of fostering selfregulated learning among students. A meta-analysis on intervention studies at primary and secondary school level. Metacognition Learning 3(3):231-264. http://dx.doi.org/10.1007/ s11409-008-9029-X

Doran, C., and R. J. Cameron. 1995. Learning about learning: metacognitive approaches in the classroom. Educational Psychology in Practice 11(2):15-23. http://dx.doi. org/10.1080/0266736950110203

Driver, R., H. Asoko, J. Leach, P. Scott, and E. Mortimer. 1994. Constructing scientific knowledge in the classroom. Educational Researcher 23(7):5-12. http://dx.doi.org/10.3102/0013189X023007005

Duschl, R., S. Maeng, and A. Sezen. 2011. Learning progressions and teaching sequences: a review and analysis. Studies in Science Education 47(2):123-182. http://dx.doi.org/10.1080/03057267.2011.604476

Duschl, R. A., H. A. Schweingruber, and A. W. Shouse, editors. 2007. Taking science to school: learning and teaching science in grades $K-8$. National Academies Press, Washington, D.C., USA.

Dyk, P. H., and S. M. Wilson. 1999. Family-based social capital considerations as predictors of attainments among Appalachian 
youth. Sociological Inquiry 69(3):477-503. http://dx.doi. org/10.1111/j.1475-682X.1999.tb00882.x

Eisenhauer, B. W., R. S. Krannich, and D. J. Blahna. 2000. Attachment to special places on public lands: an analysis of activities, reason for attachments, and community connections. Society and Natural Resources 13(5):421-441. http://dx.doi. org/10.1080/089419200403848

Ernst, K. M., and M. van Riemsdijk. 2013. Climate change scenario planning in Alaska's National Parks: stakeholder involvement in the decision-making process. Applied Geography 45:22-28. http://dx.doi.org/10.1016/j.apgeog.2013.08.004

Evans, C., E. Abrams, R. Reitsma, K. Roux, L. Salmonsen, and P. P. Marra. 2005. The Neighborhood Nestwatch Program: participant outcomes of a citizen-science ecological research project. Conservation Biology 19(3):589-594. http://dx.doi. org/10.1111/j.1523-1739.2005.00s01.x

Fazey, I., J. A. Fazey, J. Fischer, K. Sherren, J. Warren, R. F. Noss, and S. R. Dovers. 2007. Adaptive capacity and learning to learn as leverage for social-ecological resilience. Frontiers in Ecology and the Environment 5(7):375-380. http://dx.doi.org/10.1890/1540-9295 (2007)5[375:ACALTL]2.0.CO;2

Ferguson, K. M. 2006. Social capital and children's wellbeing: a critical synthesis of the international social capital literature. International Journal of Social Welfare 15(1):2-18. http://dx.doi. org/10.1111/j.1468-2397.2006.00575.X

Flavell, J. H., F. L. Green, and E. R. Flavell. 1995. Young children's knowledge about thinking. Monographs of the Society for Research in Child Development 60(1):1-95. http://dx.doi. org/10.2307/1166124

Folke, C., F. S. Chapin III, and P. Olsson. 2009. Transformations in ecosystem stewardship. Pages 103-125 in F. S. Chapin III, G. P. Kofinas, and C. Folke, editors. Principles of ecosystem stewardship: resilience-based natural resource management in a changing world. Springer, New York, New York, USA. http://dx. doi.org/10.1007/978-0-387-73033-2 5

Furstenberg, F. F. Jr., and M. E. Hughes. 1995. Social capital and successful development among at-risk youth. Journal of Marriage and Family 57(3):580-592. [online] URL: http://www.jstor.org/ stable/353914.

Gray, S., A. Chan, D. Clark, and R. Jordan. 2012. Modeling the integration of stakeholder knowledge in social-ecological decision-making: benefits and limitations to knowledge diversity. Ecological Modeling 229:88-96. http://dx.doi.org/10.1016/j. ecolmode1.2011.09.011

Hennessey, M. G. 1991. Analysis of conceptual change and status change in sixth graders' concepts of force and motion. Dissertation. University of Wisconsin, Madison, Wisconsin, USA.

Hicks, D., and C. Holden. 1995. Exploring the future: a missing dimension in environmental education. Environmental Education Research 1(2):185-193. http://dx.doi.org/10.1080/1350462950010205

Hinzman, L. D., N. D. Bettez, W. R. Bolton, F. S. Chapin, M. B. Dyurgerov, C. L. Fastie, B. Griffith, R. D. Hollister, A. Hope, H. P. Huntington, A. M. Jensen, G. J. Jia, T. Jorgenson, D. L. Kane, D. R. Klein, G. Kofinas, A. H. Lynch, A. H. Lloyd, A. D.
McGuire, F. E. Nelson, W. C. Oechel, T. E. Osterkamp, C. H. Racine, V. E. Romanovsky, R. S. Stone, D. A. Stow, M. Sturm, C. E. Tweedie, G. L. Vourlitis, M. D. Walker, D. A. Walker, P. J. Webber, J. M. Welker, K. S. Winker, and K. Yoshikawa. 2005. Evidence and implications of recent climate change in northern Alaska and other Arctic regions. Climatic Change 72(3):251-298. http://dx.doi.org/10.1007/s10584-005-5352-2

Hung, W. 2008. Enhancing systems-thinking skills with modelling. British Journal of Educational Technology 39 (6):1099-1120. http://dx.doi.org/10.1111/j.1467-8535.2007.00791. $\underline{\mathrm{x}}$

Huntington, H. P., L. C. Hamilton, C. Nicolson, R. Brunner, A. Lynch, A. E. J. Ogilvie, and A. Voinov. 2007. Toward understanding the human dimensions of the rapidly changing arctic system: insights and approaches from five HARC projects. Regional Environmental Change 7(4):173-186. http://dx.doi. org/10.1007/s10113-007-0038-0

Jones, A., C. Buntting, R. Hipkins, A. McKim, L. Conner, and K. Saunders. 2011. Developing students' futures thinking in science education. Research in Science Education 42(4):687-708. http://dx.doi.org/10.1007/s11165-011-9214-9

Jordan, R. C., H. L. Ballard, and T. B. Phillips. 2012. Key issues and new approaches for evaluating citizen-science learning outcomes. Frontiers in Ecology and the Environment 10 (6):307-309. http://dx.doi.org/10.1890/110280

Jordan, R., S. Gray, M. Demeter, L. Lui, and C. E. Hmelo-Silver. 2009. An assessment of students' understanding of ecosystem concepts: conflating ecological systems and cycles. Applied Environmental Education and Communication 8(1):40-48. http:// dx.doi.org/10.1080/15330150902953472

Jordan, R. C., S. A. Gray, D. V. Howe, W. R. Brooks, and J. G. Ehrenfeld. 2011. Knowledge gain and behavioral change in citizen-science programs. Conservation Biology 25(6):1148-1154. http://dx.doi.org/10.1111/j.1523-1739.2011.01745.x

Kevany, K. D. 2007. Building the requisite capacity for stewardship and sustainable development. International Journal of Sustainability in Higher Education 8(2):107-122. http://dx.doi. org/10.1108/14676370710726580

Kofinas, G. P. 2009. Adaptive co-management in social-ecological governance. Pages 77-101 in F. S. Chapin III, G. P. Kofinas, and C. Folke, editors. Principles of ecosystem stewardship: resiliencebased natural resource management in a changing world. Springer, New York, New York, USA. http://dx.doi.org/10.1007/978-0-387-73033-2 4

Kofinas, G. P., F. S. Chapin, S. BurnSilver, J. I. Schmidt, N. L. Fresco, K. Kielland, S. Martin, A. Springsteen, and T. S. Rupp. 2010. Resilience of Athabascan subsistence systems to interior Alaska's changing climate. Canadian Journal of Forest Research 40(7):1347-1359. http://dx.doi.org/10.1139/X10-108

Krasny, M. E. 2009. A response to Scott's concerns about the relevance of environmental education research: applying socialecological systems thinking and consilience to defining research goals. Environmental Education Research 15(2):189-198. http://dx. doi.org/10.1080/13504620902770352 
Krasny, M. E., L. Kalbacker, R. C. Stedman, and A. Russ. 2013. Measuring social capital among youth: applications in environmental education. Environmental Education Research 21 (1):1-23. http://dx.doi.org/10.1080/13504622.2013.843647

Krasny, M. E., and K. G. Tidball. 2009a. Applying a resilience systems framework to urban environmental education. Environmental Education Research 15(4):465-482. http://dx.doi. org/10.1080/13504620903003290

Krasny, M. E., and K. G. Tidball. 2009b. Community gardens as context for science, stewardship and advocacy learning: the garden mosaics example. Cities and the Environment 2(1): article 8 .

Krasny, M. E., K. G. Tidball, and N. Sriskandarajah. 2009. Education and resilience: social and situated learning among university and secondary students. Ecology and Society 14(2): 38. [online] URL: http://www.ecologyandsociety.org/vol14/iss 2/ art38/.

Kudryavtsev, A., M. E. Krasny, and R. C. Stedman. 2012a. The impact of environmental education on sense of place among urban youth. Ecosphere 3(4): art29. http://dx.doi.org/10.1890/ ES11-00318.1

Kudryavtsev, A., R. C. Stedman, and M. E. Krasny. 2012b. Sense of place in environmental education. Environmental Education Research 18(2):229-250. http://dx.doi.org/10.1080/13504622.2011.609615

Kyburz-Graber, R., K. Hofer, and B. Wolfensberger. 2006. Studies on a socio-ecological approach to environmental education: a contribution to a critical position in the education for sustainable development discourse. Environmental Education Research 12 (1):101-114. http://dx.doi.org/10.1080/13504620500527840

Lee, H.-S., and O. L. Liu. 2010. Assessing learning progression of energy concepts across middle school grades: the knowledge integration perspective. Science Education 94(4):665-688. http:// dx.doi.org/10.1002/sce.20382

Liedtka, J. M. 1998. Strategic thinking: can it be taught? Long Range Planning 31(1):120-129. http://dx.doi.org/10.1016/S0024-6301 (97)00098-8

Louv, R. 2008. Last child in the woods: saving our children from nature-deficit disorder. Algonquin Books, Chapel Hill, North Carolina, USA.

Maldonado, J. K., C. Shearer, R. Bronen, K. Peterson, and H. Lazrus. 2013. The impact of climate change on tribal communities in the US: displacement, relocation, and human rights. Climatic Change 120(3):601-614. http://dx.doi.org/10.1007/s10584-013-0746$\underline{\mathrm{z}}$

Markon, C. J., S. F. Trainor, and F. S. Chapin III, editors. 2012. The United States national climate assessment: Alaska technical regional report. Circular 1379. U.S. Geological Survey, Anchorage, Alaska, USA. [online] URL: http://pubs.usgs.gov/ circ/1379/pdf/circ1379.pdf.

MEA [Millenium Ecosystem Assessment]. 2005. Ecosystems and human well-being: scenarios. Island Press, Washington, D.C., USA. [online] URL: http://www.millenniumassessment.org/en/ Scenarios.html.
Meadows, D. H. 2008. Thinking in systems: a primer. Chelsea Green Publishing, White River Junction, Vermont, USA.

Mietzner, D., and G. Reger. 2005. Advantages and disadvantages of scenario approaches for strategic foresight. International Journal of Technology Intelligence and Planning 1(2):220-239. http://dx.doi.org/10.1504/IJTIP.2005.006516

Miller, B. 1992. Collective action and rational choice: place, community and the limits to individual self-interest. Economic Geography 68(1):22-42. http://dx.doi.org/10.2307/144039

Muttarak, R., and W. Lutz. 2014. Is education a key to reducing vulnerability to natural disasters and hence unavoidable climate change? Ecology and Society 19(1): 42. http://dx.doi.org/10.5751/ ES-06476-190142

NRC [National Research Council]. 2012. A framework for $K-12$ science education: practices, crosscutting concepts, and core ideas. Committee on a Conceptual Framework for New K-12 Science Education Standards. Board on Science Education, Division of Behavioral and Social Sciences and Education. National Academies Press, Washington, D.C., USA. [online] URL: http:// www.nap.edu/catalog/13165/a-framework-for-k-12-science-educationpractices-crosscutting-concepts.

Ornauer, H., H. Wiberg, A. Sicinski, and J. Galtung, editors. 1976. Images of the world in the year 2000: a comparative ten nation study. Humanities Press, Atlantic Highlands, New Jersey, USA.

Ostrom, E. 1990. Governing the commons. Cambridge University Press, Cambridge, UK. http://dx.doi.org/10.1017/CBO9780511807763

Ostrom, E. 2000. Social capital: a fad or a fundamental concept? Pages 172-214 in P. Dasgupta and I. Seragilden, editors. Social capital: a multifaceted perspective. World Bank, Washington, D. C., USA. [online] URL: http://documents.worldbank.org/ curated/en/1999/09/439794/social-capital-multifaceted-perspective.

Pandya, R. E. 2012. A framework for engaging diverse communities in citizen science in the US. Frontiers in Ecology and the Environment 10(6):314-317. http://dx.doi.org/10.1890/120007

Peterson, G. D., T. D. Beard Jr., B. E. Beisner, E. M. Bennett, S. R. Carpenter, G. S. Cumming, C. L. Dent, and T. D. Havlicek. 2003. Assessing future ecosystem services: a case study of the Northern Highlands Lake District, Wisconsin. Conservation Ecology 7(3): 1. [online] URL: http://www.consecol.org/vol7/iss3/ art1.

Plummer, R., and J. FitzGibbon. 2007. Connecting adaptive comanagement, social learning, and social capital through theory and practice. Pages 38-61 in D. Armitage, F. Berkes, and N. Doubleday. Adaptive co-management: collaboration, learning, and multi-level governance. UBC Press, Vancouver, Canada.

Putnam, R. D. 1995. Bowling alone: America's declining social capital. Journal of Democracy 6(1):65-78. http://dx.doi. org/10.1353/jod.1995.0002

Riess, W., and C. Mischo. 2010. Promoting systems thinking through biology lessons. International Journal of Science Education 32(6):705-725. http://dx.doi.org/10.1080/09500690902769946

Rioux, L. 2011. Promoting pro-environmental behaviour: collection of used batteries by secondary school pupils. 
Environmental Education Research 17(3):353-373. http://dx.doi. org/10.1080/13504622.2010.543949

Robertson, G. P., S. L. Collins, D. R. Foster, N. Brokaw, H. W. Ducklow, T. L. Gragson, C. Gries, S. K. Hamilton, A. D. McGuire, J. C. Moore, E. H. Stanley, R. B. Waide, and M. W. Williams. 2012. Long-term ecological research in a humandominated world. BioScience 64(4):342-353. http://dx.doi. org/10.1525/bio.2012.62.4.6

Rosencwajg, P. 2003. Metacognitive factors in scientific problemsolving strategies. European Journal of Psychology of Education 18(3):281-294. http://dx.doi.org/10.1007/BF03173249

Russell, R., A. D. Guerry, P. Balvanera, R. K. Gould, X. Basurto, K. M. A. Chan, S. Klain, J. Levine, and J. Tam. 2013. Humans and nature: how knowing and experiencing nature affect wellbeing. Annual Review of Environment and Resources 38:473-502. http://dx.doi.org/10.1146/annurev-environ-012312-110838

Ryan, R. L. 2005. Exploring the effects of environmental experience on attachment to urban natural areas. Environment and Behavior 37(1):3-42. http://dx.doi.org/10.1177/0013916504264147

Semken, S., C. Butler Freeman, N. Bueno Watts, J. J. Neakrase, and R. Escobar Dial. 2009. Factors that influence sense of place as a learning outcome and assessment measure of place-based geoscience teaching. Electronic Journal of Science Education 13 (2). [online] URL: http://ejse.southwestern.edu/article/view/7803.

Senge, P. M. 1990. The fifth discipline: the art and practice of the learning organization. Doubleday Currency Press, New York, New York, USA.

Shirk, J. L., H. L. Ballard, C. C. Wilderman, T. Phillips, A. Wiggins, R. Jordan, E. McCallie, M. Minarchek, B. V. Lewenstein, M. E. Krasny, and R. Bonney. 2012. Public participation in scientific research: a framework for deliberate design. Ecology and Society 17(2): 29. http://dx.doi.org/10.5751/ ES-04705-170229

Sigman, M., and B. Trowbridge. 2004. CoastWalk 20th anniversary newsletter. Center for Alaskan Coastal Studies, Homer, Alaska, USA. [online] URL: http://www.akcoastalstudies. org/Pdf/2004coastwalknewsletter.pdf.

Silvertown, J. 2009. A new dawn for citizen science. Trends in Ecology and Evolution 24(9):467-471. http://dx.doi.org/10.1016/j. tree.2009.03.017

Simonneaux, J., and L. Simonneaux. 2012. Educational configurations for teaching environmental socioscientific issues within the perspective of sustainability. Research in Science Education 42(1):75-94. http://dx.doi.org/10.1007/s11165-011-9257y

Spellman, K. V. 2015. Invasive plants and pollination of Alaskan berry species: integrating ecology and education. Dissertation. University of Alaska Fairbanks, Fairbanks, Alaska, USA.

Sriskandarajah, N., R. Bawden, C. Blackmore, K. G. Tidball, and A. E. J. Wals. 2010. Resilience in learning systems: case studies in university education. Environmental Education Research 16 (5-6):559-573. http://dx.doi.org/10.1080/13504622.2010.505434
Stedman, R. C. 2002. Toward a social psychology of place: predicting behavior from place-based cognitions, attitude, and identity. Environment and Behavior 34:405-425. http://dx.doi. org/10.1177/0013916502034005001

Sterling, S. 2003. Whole systems thinking as a basis for paradigm change in education: explorations in the context of sustainability. Dissertation. University of Bath, Bath, UK. [online] URL: http:// www.bath.ac.uk/cree/sterling/index.htm.

Sterling, S. 2010. Learning for resilience, or the resilient learner? Towards a necessary reconciliation in a paradigm of sustainable education. Environmental Education Research 16(5-6):511-528. http://dx.doi.org/10.1080/13504622.2010.505427

Sterman, J. D., and L. B. Sweeney. 2007. Understanding public complacency about climate change: adults' mental models of climate change violate conservation of matter. Climatic Change 80(3-4):213-238. http://dx.doi.org/10.1007/s10584-006-9107-5

Thomas, G. P., and C. J. McRobbie. 2001. Using a metaphor for learning to improve students' metacognition in the chemistry classroom. Journal of Research in Science Teaching 38(2):222-259. http://dx.doi.org/10.1002/1098-2736(200102)38:2<222::AIDTEA1004>3.0.CO;2-S

Tidball, K. G., and M. E. Krasny. 2010. Urban environmental education from a social-ecological perspective: conceptual framework for civic ecology education. Cities and the Environment 3(1): 11 .

Tidball, K. G., and M. E. Krasny. 2011. Toward an ecology of environmental education and learning. Ecosphere 2(2): art21. http://dx.doi.org/10.1890/ES10-00153.1

Tidball, K. G., and M. E. Krasny. 2012. A role for citizen science in disaster and conflict recovery and resilience. Pages 226-234 in J. L. Dickinson and R. Bonney, editors. Citizen science: public participation in environmental research. Cornell University Press, Ithaca, New York, USA.

Trowbridge, B., M. Sigman, B. Murphy, L. Villarreal, and K. Mangin. 2004. Gulf of Alaska CoastWatch curriculum guide. Center for Alaskan Coastal Studies, Homer, Alaska, USA. [online] URL: http://www.akcoastalstudies.org/Pdf/CoastWatchProgram. pdf.

Tschakert, P., and K. A. Dietrich. 2010. Anticipatory learning for climate change adaptation and resilience. Ecology and Society 15 (2): 11. [online] URL: http://www.ecologyandsociety.org/vol15/ iss $2 / \operatorname{art11} /$.

Tuan, Y.-F. 1977. Space and place: the perspective of experience. University of Minnesota Press, Minneapolis, Minnesota, USA.

Turnbull, D. J., R. Bonney, D. Bascom, and A. Cabral. 2000. Thinking scientifically during participation in a citizen-science project. Science Education 84(2):265-275. http://dx.doi. org/10.1002/(SICI)1098-237X(200003)84:2<265::AID-SCE7>3.0. CO;2-5

Walker, B. H., and D. Salt. 2006. Resilience thinking: sustaining ecosystems and people in a changing world. Island Press, Washington, D.C., USA. 
Walker, G. J., and R. Chapman. 2003. Thinking like a park: the effects of sense of place, perspective-taking, and empathy on proenvironmental intentions. Journal of Park and Recreation Administration 21(4):71-86. [online] URL: http://js.sagamorepub. com/jpra/article/view/1492/1457.

Wilson, R. 1997. A sense of place. Early Childhood Education Journal 24(3):191-194. http://dx.doi.org/10.1007/BF02353278

Wylie, J., N. Sheehy, C. McGuinness, and G. Orchard. 1998. Children's thinking about air pollution: a systems theory analysis. Environmental Education Research 4(2):117-137. http://dx.doi. org/10.1080/1350462980040201

Yueh, M.-C. M., B. Cowie, M. Barker, and A. Jones. 2010 What influences the emergence of a new subject in schools? The case of environmental education. International Journal of Environmental and Science Education 5(3):265-285. [online] URL: http://www. ijese.com/IJESE v5n3 Yueh-et-al.pdf. 